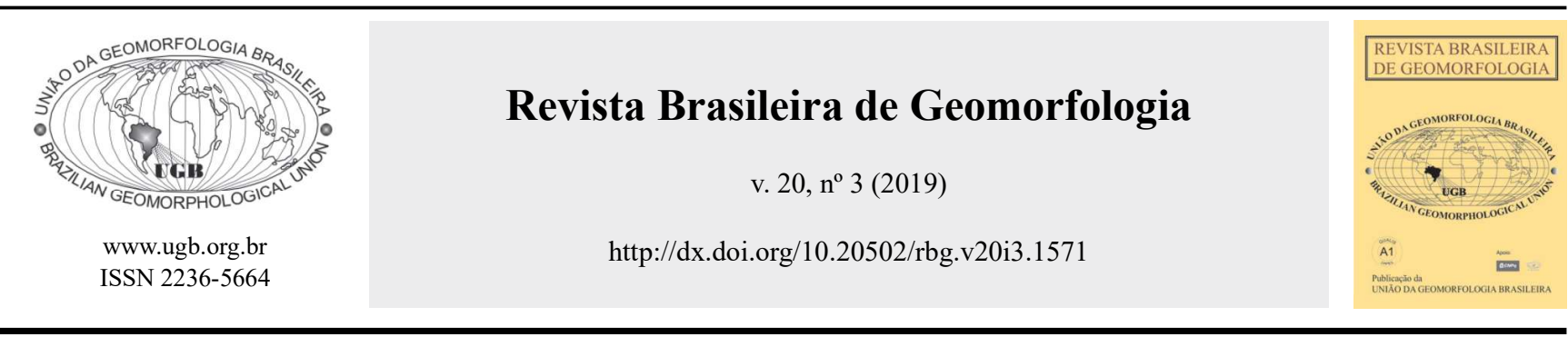

\title{
MAPEAMENTO GEOMORFOLÓGICO E GEOMORFOLOGIA ANTROPOGÊNICA DO MUNICÍPIO DO CONDE - PARAÍBA
}

\section{GEOMORPHOLOGICAL MAPPING AND ANTHROPOGENIC GEOMORPHOLOGY OF CONDE MUNICIPALITY - PARAIIBA}

Tamires Silva Barbosa

Programa de Pós-graduação em Geografia, Universidade Federal da Paraíba Cidade Universitária, s/n, João Pessoa, Paraíba. CEP: 58051-900. Brasil ORCID: 0000-0002-6590-1489

E-mail: mires.ufpb@gmail.com

Vinicius Ferreira de Lima

Programa de Pós-graduação em Geografia, Universidade Federal da Paraíba Cidade Universitária, s/n, João Pessoa, Paraíba. CEP: 58051-900. Brasil

ORCID: 0000-0001-5338-3031

E-mail:viniciusgeo_lima@hotmail.com

\author{
Max Furrier \\ Departamento de Geociências, Universidade Federal da Paraíba \\ Cidade Universitária, s/n, João Pessoa, Paraíba. CEP: 58051-900. Brasil \\ ORCID: 0000-0001-8882-5290 \\ E-mail:max_furrier@hotmail.com
}

\begin{tabular}{l} 
Informações sobre o Artigo \\
\hline Recebido (Received): \\
07/01/2019 \\
Aceito (Accepted): \\
25/06/2019 \\
\hline
\end{tabular}

Palavras-chave:

Relevo Antropogênico; Morfogênese Antropogênica; Depósitos Tecnogênicos;

Tecnogênese.

\section{Keywords:}

Anthropogenic Relief; Anthropogenic Morphogenesis; Technogenic Deposits; Technogenesis.

\section{Resumo:}

O presente artigo traz uma contribuição aos estudos da geomorfologia antropogênica, aplicando o mapeamento geomorfológico como ferramenta para identificação de formas de relevo antropogênicas. O objetivo principal desta pesquisa é identificar estas formas antropogênicas, mapeá-las, quando possível classifica-las e analisar os processos que deram origem as mesmas. Como principais procedimentos técnicos operacionais, pode-se descrever: a vetorização de cartas topográficas que abarcam o município do Conde - PB na escala 1:25.000, contendo curvas de nível de equidistância de $10 \mathrm{~m}$; a utilização desses vetores em um ambiente SIG para formar uma base de dados, possibilitando a produção de modelos do terreno em 3D e mapas temáticos de hipsometria e declividade; a produção nesse mesmo ambiente SIG do mapa geomorfológico, possibilitando a inserção de dados coletados em campo para a complementação desse mapa no que diz respeito às formas antropogênicas. Os trabalhos de campo foram fundamentais para a finalização do mapeamento e para a análise das formas antropogênicas e seus processos. Pôde-se identificar nesse município formas antropogênicas relacionadas às atividades de mineração e extração de areia, que deram origem a formas denudacionais ou de erosão; rios com planícies de inundação alteradas; voçorocas urbanas com ocupações que avançam em direção às cidades; voçorocas 
em áreas de loteamento; áreas de erosão costeira com forte influência da ação humana, entre outras. Cada uma dessas formas pode mostrar um cenário atual ou futuro de riscos geomorfológicos, além da modificação dos processos morfogenéticos da região.

\begin{abstract}
:
This paper will contribute to the study of anthropogenic geomorphology, applying geomorphological mapping as a tool to identify anthropogenic relief forms. The main objective of this research is to identify the anthropogenic forms, map them, and when possible classify them and analyze the processes that gave rise to them. The main operational technical procedures can be described: the vectorization of topographic charts covering the municipality of Conde, containing equidistance level curves of 10 meters and a scale of 1:25,000; the use of these vectors in a GIS environment to form a database making possible the production of 3D terrain models and thematic maps of hypsometry and slope; the production in this same GIS environment of the geomorphological map, making possible the insertion of data collected in the field to complement the map with respect to the anthropogenic forms. The field work was essential to the completion of the mapping and analysis of anthropogenic forms and processes. In this municipality anthropogenic forms could be identified related to the activities of mining and sand extraction, which gave rise to denudational or erosion forms; rivers with altered flood plains; gullies with urban occupations advancing toward the same; coastal gullies; coastal erosion areas strongly influenced by human action, among others. Each of these forms can show a current or future scenario of geomorphological risks, besides the modification of the morphogenetic processes of the region.
\end{abstract}

\section{Introdução}

A geomorfologia se refere ao estudo das formas de relevo da Terra. É sabido que mapear formas de relevo não é uma tarefa tão simples quanto mapear "objetos concretos" que podem ser encontrados na superfície terrestre, pois ao mapear relevo, mapeia-se o aspecto, a forma e o comportamento da parte mais superficial da Terra, que está em constante modificação.

Concordando com Ross (1992), a questão de taxonomia e a representação cartográfica do relevo tem sempre revelado grande dificuldade de solução em face à natureza do fenômeno a ser representado. As formas são tridimensionais, bem como de diferentes tamanhos, formatos, gêneses e idades. Diante disso, têm-se muitas propostas de representação de relevo, e não há uma padronização real para esse tipo de mapeamento. Alguns mapas sempre valorizarão algum aspecto em detrimento a outro, dependendo do foco da pesquisa.

Assim, tratando-se de pesquisas que focam o mapeamento e análise de formas antropogênicas, que são muito mais dinâmicas e complexas devido à atuação constante do homem com velocidade muito superior à dos agentes endógenos e exógenos, os mapeamentos geomorfológicos que queiram abarcar as formas antropogênicas necessitarão de ajustes metodológicos devido à escala desses fenômenos.
O objetivo deste trabalho é, através do mapeamento geomorfológico, conseguir identificar, mapear, analisar e classificar as formas de relevo antropogênicas situadas no município do Conde, Paraíba.

Das técnicas e caminhos já estabelecidos para mapeamento geomorfológico, esta pesquisa seguirá a desenvolvida por Ross (1992), sendo que algumas modificações e adaptações serão feitas em virtude das características próprias da área de estudo e também para que sejam focadas as formas relacionadas ao $6^{\circ}$ táxon da metodologia de Ross, que são as feições atuais naturais e antropogênicas.

Outras metodologias como, por exemplo, a de Peloggia et al. (2014) e Peloggia et al. (2018), que focam, especificamente, no mapeamento de formas antropogênicas, são utilizadas em partes neste trabalho, principalmente no que diz respeito aos termos utilizados para a descrição das formas antropogênicas. Isso acontece porque o mapeamento empregado nesses trabalhos é aplicado a pequenas áreas, dando origem a um mapeamento de escala muito grande, o que não corresponde à área de estudo escolhida nesta pesquisa. Portanto, para esta pesquisa se fez necessário adaptar a metodologia de Peloggia et al. (2018) para gerar um mapeamento de menor detalhe. Dessa forma, o grande desafio é realizar esse mapeamento de formas antropogênicas em grandes áreas. 
As formas de relevo antropogênicas, que também podem ser denominadas de relevo tecnogênico, são formas originadas direta ou indiretamente pela ação humana. O estudo desse tipo de feição de relevo é importante, pois o homem tem modificado intensamente a superfície terrestre, podendo ser considerado, por alguns autores, como Peloggia et al. (2014) e Hooke (1994), um agente geomorfológico comparável aos agentes naturais ou até superior a eles, em alguns casos.

Conforme relata Hooke (1994), o ser humano é um agente geomórfico que move grandes quantidades de solo e rocha, e é responsável pelos impactos mais visíveis da paisagem, agindo de maneira direta ou indireta, para produzir formas de relevo ou modificar processos morfogenéticos.

Goudie (2013) relata a importância dos estudos geomorfológicos em que o homem é considerado um agente morfogenético, porém também traz a problemática de que no Ocidente esses estudos ainda são incipientes e não têm sido tão explorados quanto deveriam. Portanto, ressalta-se ainda mais a necessidade de pesquisas nesta linha, que forneçam novos dados e formas de analisar o relevo antropogênico.

$\mathrm{O}$ que se tem observado nos estudos de relevo antropogênico é que as pesquisas realizadas no Brasil têm maior foco em áreas da região Sudeste, como se pode ver nos trabalhos de Peloggia et al. (2018), Braga et al. (2016), Figueira (2007), Gouveia (2010), Rodrigues (2005), Luz e Rodrigues (2015), entre outros. Apesar de o Sudeste ser a região mais urbanizada do Brasil, estudos de outras regiões são importantes para enriquecer e abrir o leque da produção neste campo de conhecimento.

A geomorfologia antropogênica estuda todos os processos que geram formas de relevo de origem antropogênica e/ou as alterações de alguma geoforma já antes estabelecida, sendo a ação humana direta ou indireta (NIR, 1983). Assim, o escopo da antropogeomorfologia não inclui somente o estudo de formas de relevo produzidas pelo homem, mas também as alterações da superfície terrestre induzidas pelo homem, os fenômenos que podem perturbar o equilíbrio natural do geossistema, bem como a formulação de propostas a fim de evitar e mitigar impactos nocivos, a exemplo dos riscos geológicos (SZABÓ, 2010).

Para aplicação do mapeamento geomorfológico e análise das formas antropogênicas, escolheu-se o munícipio do Conde - PB, por ser um município com a malha urbana situada, principalmente, nos Baixos
Planaltos Costeiros esculpidos sobre a Formação Barreiras. A morfologia é constituída principalmente por topos tabulares, gerando situações diferenciadas de urbanização sobre essas formas de relevo, além de ter uma rede hidrográfica relativamente densa em relação aos municípios de seu entorno, e fortes indícios de erosão do solo por elementos naturais e também antrópicos. Por fim, o seu litoral é marcado por intensa ação erosiva em sua linha de costa e também são verificadas inúmeras voçorocas nas falésias inativas.

\section{2. Área de Estudo}

A área de estudo consiste no município do Conde, litoral do estado da Paraíba, Nordeste do Brasil. Este município está localizado na mesorregião da Zona da Mata Paraibana e na Microrregião de João Pessoa. Segundo o Serviço Geológico do Brasil (CPRM, 2005) a área do município do Conde é de $173 \mathrm{~km}^{2}$. A sede do município tem uma altitude aproximada de $112 \mathrm{~m}$, distando 16,8 km da capital paraibana (Figura 1).

O município do Conde é limitado a leste pelo oceano Atlântico, ao norte com o município de João Pessoa, ao Oeste com os municípios de Alhandra e Santa Rita, e ao Sul com o município de Pitimbu. O município está inserido nas Folhas da Superintendência de Desenvolvimento do Nordeste (SUDENE, 1970) do Conde, Jacumã, Nossa Senhora da Penha e Santa Rita, todas na escala de 1:25.000. Por isso, estas cartas topográficas serão utilizadas como base cartográfica para os estudos geomorfológicos do município.

Quanto aos aspectos geológicos da área, pode-se destacar a Bacia Sedimentar Marginal da Paraíba, que é preenchida por sedimentos de fácies continentais e marinhas, reunidas sob a denominação de Grupo Paraíba, que, por sua vez, é subdividido em três formações: Beberibe, Gramame e Maria Farinha (CPRM, 2002). A Formação Gramame, composta por calcários do Cretáceo, aflora, principalmente, no vale do rio Graú, e a Formação Maria Farinha, composta por calcários do Paleoceno aflora, de forma bastante descontínua, na linha de costa, influenciado de maneira conspícua toda a configuração desta (Figura 2). Capeando o Grupo Paraíba e compondo a maior parte da superfície do Conde está a Formação Barreiras, formada por sedimentos arenoargilosos do Mioceno. Nas planícies e terraços costeiros são encontrados sedimentos inconsolidados do Quaternário. 


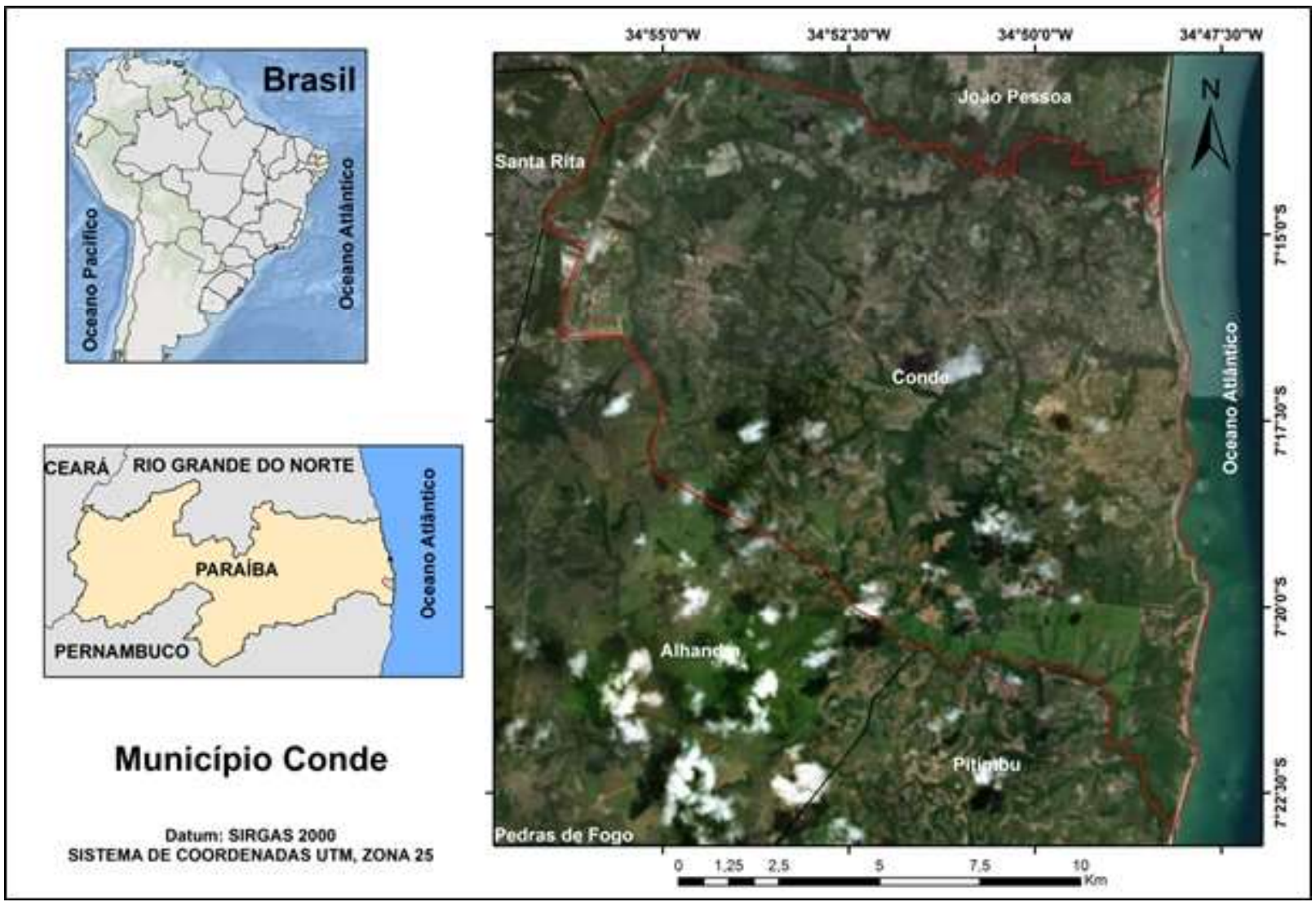

Figura 1 - Mapa de localização do município do Conde - PB. Fonte: Elaboração própria (2018).

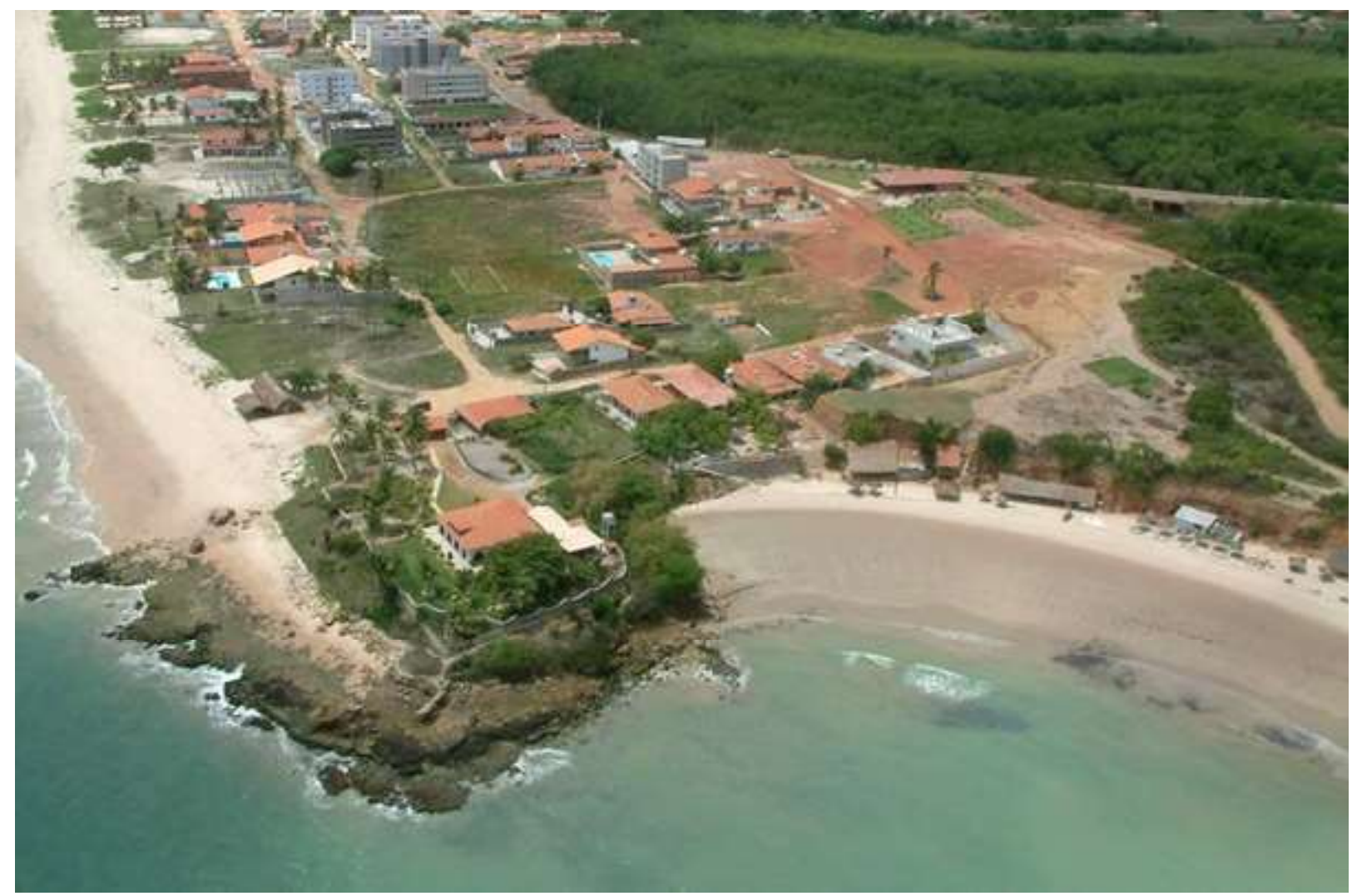

Figura 2 - Afloramento da Formação Maria Farinha na linha de costa (Foto: Ricardo Paulo, 2002). 


\section{Mapeamento Geomorfológico e Geomorfologia Antropogênica do Município do Conde - Paraíba}

O município do Conde está inserido nos Baixos Planaltos Costeiros. Esta unidade morfológica está presente em praticamente todo o litoral da região Nordeste e apresenta altitude média entre 50 a 100 $\mathrm{m}$. Compreende platôs de origem sedimentar que apresentam grau de entalhamento variável, ora com vales estreitos e encostas abruptas, ora com vales abertos, encostas suaves e fundos com amplas planícies fluviais e estuarinas (CPRM, 2005).

No município do Conde, os Baixos Planaltos Costeiros apresentam-se mais dissecados, com uma densidade de drenagem mais elevada e feições de caráter tectônico-estrutural como o Alto de Coqueirinho (FURRIER et al., 2006). No município, o relevo apresenta, por vezes, superfícies planas e também superfícies ligeiramente onduladas, formando, assim, um conjunto de formas de relevo tabulares e semiconvexas. A planície litorânea é bastante estreita, sendo confinada pelas falésias ativas e inativas da Formação Barreiras.

Conforme CPRM (2005), o clima dessa região é do tipo Tropical Chuvoso com verão seco. A precipitação média anual no município é de $1.634 \mathrm{~mm}$. O período chuvoso começa no outono, tendo início em fevereiro e término em outubro. Devido à quantidade de chuvas na região, os solos são pobres em nutrientes e bastante lixiviados, principalmente nos topos dos tabuleiros. Os principais solos encontrados são os Argissolos Vermelho-Amarelos distróficos e os Espodossolos Hidromórficos (FURRIER, 2007), ambos com alta concentração de areia.

As principais bacias hidrográficas presentes na área são as bacias dos rios Guruji, Graú, da Salsa, Boa Água e Gramame, que são formadas por rios perenes. O principal rio e o mais volumoso é o rio Gramame.

\section{Procedimentos Metodológicos}

Para a execução inicial da pesquisa proposta, primeiramente foram reunidos materiais cartográficos e bibliográficos para auxílio ao mapeamento geomorfológico e para a fundamentação teórica da pesquisa. Assim, foram selecionadas cartas topográficas da Sudene (1974), que são as Folhas Nossa Senhora da Penha, Santa Rita, João Pessoa, Conde, Jacumã e Mata da Aldeia como material cartográfico base. Todas as cartas topográficas utilizadas possuem escala de 1:25.000 e curvas de nível com equidistância de $10 \mathrm{~m}$.
As cartas topográficas utilizadas foram elaboradas mediante o método fotogramétrico de triangulação de área, com apoio de técnicos no terreno para traçar numerosos pontos altimétricos. Portanto, embora tenha necessitado muito mais trabalho, a vetorização dessas cartas topográficas forneceu uma precisão muito superior às imagens orbitais obtidas por meio do radar Shuttle Radar Topographic Mission (SRTM).

Assim, a vetorização dessas cartas deu origem a dados topográficos digitais que foram lançados em ambiente de Sistema de Informação Geográfica (SIG) Spring 5.5.2 e, então, trabalhados para geração dos mapas de localização, Modelo Digital do Terreno (MDT), adaptação do mapa geológico e geração do mapa geomorfológico.

Para gerar o mapa geomorfológico, foi utilizada a metodologia de Ross (1992), principalmente para determinação dos $1^{\circ}, 2^{\circ}, 3^{\circ}$ e $4^{\circ}$ táxons, que determinam, respectivamente: a morfoestrutura, a morfoescultura, os padrões de formas de relevo e os tipos de formas de relevo. O $5^{\circ}$ táxon, que corresponde aos tipos de formas de vertentes, geralmente seria feito mediante perfis topográficos, porém foi preferível a descrição dessas vertentes no texto, pois elas foram analisadas por meio do modelo 3D gerado em ambiente SIG e pelos trabalhos de campo. O $6^{\circ}$ táxon é, neste trabalho, o mais importante, pois determina formas atuais naturais e antropogênicas.

Para determinar as formas naturais e antropogênicas e atuais. foram usados tanto os métodos remotos, por meio de análise das imagens de satélite, como também trabalhos de campo para inferir essas formas. Devese ressaltar que o mapeamento de todas as formas antropogênicas no município seria um trabalho impossível, devido à escala empregada nesta pesquisa, portanto, foram mapeadas as formas antropogênicas possíveis de serem identificadas para esta escala proposta.

As formas antropogênicas mais pontuais de maior detalhe foram apontadas em fotografias produzidas em trabalhos de campo, com as suas devidas análises. Dessa forma, os trabalhos de campo foram cruciais para realização de todas as etapas da pesquisa. As nomenclaturas e classificações das formas nos terrenos tecnogênicos e dos processos morfogenéticos antropogênicos foram utilizadas segundo a metodologia proposta por Peloggia (2014) (Tabelas 1 e 2). 
Tabela 1: Classificação dos terrenos tecnogênicos

\begin{tabular}{|c|c|c|}
\hline \multicolumn{3}{|c|}{ CLASSIFICACAOO DE TERRENOS TECNOGENICOS } \\
\hline CLASSE & TIPO & CAMADA OU FEICCÁO TECNOGËNICA \\
\hline \multirow{5}{*}{$\begin{array}{l}\text { Terreno } \\
\text { tecnogênico de } \\
\text { Agradação }\end{array}$} & Terreno produzido $(1,2)$ & Depósitos tecnogênicos construídos \\
\hline & Terreno preenchido (2) & Depósitos tecnogênicos construídos recobrindo terreno escavado \\
\hline & Terreno tecnogênico sedimentar aluvial & Depósitos tecnogênicos sedimentares induzidos de tipo aluvial \\
\hline & Terreno tecnogênico sedimentar coluvial & Depósitos tecnogênicos induzidos de tipo coluvial \\
\hline & Terreno remobilizado & Depósitos tecnogênicos remobilizados \\
\hline \multirow{4}{*}{$\begin{array}{l}\text { Terreno } \\
\text { tecnogênico de } \\
\text { degradação }\end{array}$} & Terreno erodido & Cicatrizes de erosão criadas por processos induzidos \\
\hline & $\begin{array}{l}\text { Terreno escorregado ou marcado por cicatrizes de } \\
\text { escorregamentos }\end{array}$ & Cicatrizes de escorregamentos criadas por processos induzidos \\
\hline & Terreno movimentado ou afundado (2) & Depressões de subsidência criadas por processos induzidos \\
\hline & Terreno escavado (2) & Superficies de escavação \\
\hline Terreno & Terreno quimicamente alterado & Horizontes de solo contaminados \\
\hline $\begin{array}{l}\text { tecnogênico } \\
\text { modificado }\end{array}$ & Terreno mecanicamente alterado & Horizontes de solo compactados ou revolvidos \\
\hline Terreno & Terreno sobreposto & Perfis tecnogênicos compostos \\
\hline tecnogênico misto & Terreno complexo & Perfis tecnogênicos complexos \\
\hline
\end{tabular}

(1) No sentido original atribuido por Sherlock (1922).

(2) De acordo com a classificação de terrenos artificiais do Serviço Geológico Britânico.

Fonte: Peloggia (2014).

Tabela 2: Classificação das formas tecnogênicas segundo sua gênese

\begin{tabular}{|c|c|c|}
\hline PRINCIPAIS CATEGORIAS & GENNESE & TIPOS COMUNS \\
\hline Formas agradativas & $\begin{array}{l}\text { Superficies geomórficas produzidas por processos de elevação } \\
\text { topográfica devida à acumulação de material, notadamente } \\
\text { aterramento, ou pela intensificação da deposição de sedimentos. }\end{array}$ & $\begin{array}{l}\text { (1) Formas deposicionais sedimentares. } \\
\text { (2) Aterros em geral. }\end{array}$ \\
\hline Formas degradativas & $\begin{array}{l}\text { Superficies geomórficas produzidas ou modificadas pela remoção } \\
\text { de material geológico: diretamente por ação mecânica humana ou } \\
\text { indiretamente pela intensificação da erosão, ou mesmo pela erosão } \\
\text { natural agindo sobre depósitos tecnogênicos antigos. }\end{array}$ & $\begin{array}{l}\text { (1) Superficies naturais que sofreram } \\
\text { processos de erosão acelerada induzidos. } \\
\text { (2) Depósitos tecnogênicos anteriores } \\
\text { erodidos posteriormente. } \\
\text { (3) Superficies diretamente escavadas. }\end{array}$ \\
\hline Formas movimentadas & $\begin{array}{l}\text { Superficies e sistemas geomórficos alterados topograficamente por } \\
\text { movimentação in situ de material geológico devida a movimentos } \\
\text { de massa superficiais ou subterrâneos induzidos. }\end{array}$ & $\begin{array}{l}\text { (1) Superficies naturais que sofreram } \\
\text { processos de subsidência ou colapso. } \\
\text { (2) Formas tecnogênicas agradativas } \\
\text { anteriores posteriormente movimentadas. } \\
\text { (3) Padrões fluviais modificados. }\end{array}$ \\
\hline
\end{tabular}

Fonte: Peloggia (2014).

\section{Resultados e Discussões}

Analisando o mapa geomorfológico do município do Conde (Figura 3), pode-se descrever os seguintes táxons de relevo:

$1^{\circ}$ táxon (morfoestruturas) - como principais morfoestruturas, foram ressaltados os Sedimentos Quaternários, principalmente nas planícies fluviais e marinhas; a Cobertura Sedimentar de Plataforma, que é a Formação Barreiras, capeando os topos dos Baixos Planaltos Costeiros; e a bacia sedimentar da Paraíba, principalmente com a presença de afloramento da Formação Gramame no vale do rio Graú;

$2^{\circ}$ táxon (morfoesculturas) - como morfoesculturas, que são as grandes formas de relevo esculpidas sobre a morfoestrutura, foram definidas duas principais: a Baixada Litorânea, que compõe as planícies e terraços fluviomarinhos; e os Baixos Planaltos Costeiros, que se espalham por grande parte da extensão territorial do município do Conde (Figura 3);

$3^{\circ}$ e $4^{\circ}$ táxons - correspondem, respectivamente, aos padrões e aos tipos de formas de relevo. Para um melhor entendimento, eles serão analisados conjuntamente:

Pode-se observar quatro formas de denudação, que são:

- Dt 31: são formas de dissecação tabular com entalhamento médio do vale de intensidade média (40 - $80 \mathrm{~m})$, com dimensão interfluvial média classificada como muito grande (>1500 m). Este tipo de forma está localizado na porção sul do município do Conde, próximo à praia de Tambaba, limite com o município de Pitimbu. Este padrão 
de relevo ocupa cerca de $6 \mathrm{~km}^{2}$, sendo o conjunto de padrão de relevo de menor extensão;

- Dt 21: são formas de dissecação em topos tabulares com entalhamento médio do vale classificado como fraco $(20-40 \mathrm{~m})$ e dimensão interfluvial média muito grande $(>1500 \mathrm{~m})$. A localização de tais formas na porção estudada se encontra na região nordeste do município, nas áreas entre as bacias dos rios Gramame e Guruji, limite com o município de João Pessoa, ocupando $14 \mathrm{~km}^{2}$. É o segundo menor padrão de formas de relevo, em extensão, encontrado no município;

- Dc 31: são formas de dissecação em topos convexos com entalhamento médio do vale de intensidade média $(40-80 \mathrm{~m})$, com dimensão interfluvial média classificada como muito grande (> $1500 \mathrm{~m})$. Esta área está localizada em toda região central do município do Conde e engloba as bacias dos rios Guruji e seus afluentes, rio Graú, riacho Ipiranga e rio da Salsa. Este é o conjunto de formas de relevo de maior extensão no município, contendo cerca de $83 \mathrm{~km}^{2}$ (Figura 3).

- De 41: são formas de dissecação em topos convexos com entalhamento médio do vale de intensidade forte e com dimensão interfluvial média classificada como muito grande $(>1500$ $\mathrm{m})$. Este padrão de formas se encontra na porção oeste do município do Conde, englobando as bacias hidrográficas dos rios Gramame, Boa Água e da Salsa. É o segundo maior conjunto de padrões de formas de relevo em extensão territorial que se encontra no Conde, contendo cerca de $45 \mathrm{~km}^{2}$. É nesta área que se apresenta a região mais urbanizada do município, que corresponde à cidade do Conde. Neste táxon, algumas formas tecnogênicas foram mapeadas, como, por exemplo, voçorocas urbanas e áreas de mineração (Figura 3).

Em relação às formas agradacionais ou formas de acumulação dos $3^{\circ}$ e $4^{\circ}$ táxons, foram definidas quatro principais:

- Área de planície intermareal (Api): a planície intermareal corresponde às áreas de mangue. No município, ela ocupa uma área de $7 \mathrm{~km}^{2}$ e ocorre, principalmente, nas desembocaduras dos rios Gramame, Guruji e Graú. Importantes bacias hidrográficas do município do Conde;

- Área de planície fluvial (Apf): é justaposta ao canal fluvial (GUERRA; GUERRA, 1997), ocupa $12 \mathrm{~km}^{2}$ da área de estudo, sendo a mais extensa das áreas de acumulação de sedimentos no município. Localizada em trechos dos rios Boa Água, da Salsa, riacho Ipiranga e alguns afluentes menores.

- Área de terraço e planície marinha (Atpm): encontra-se nas áreas de praia e sua retaguarda, ocupando cerca de $4 \mathrm{~km}^{2}$ de área. A planície marinha são as áreas de praia que ainda sofrem inundação das águas marinhas, até onde a maré pode avançar; já o terraço são as antigas planícies marinhas que atualmente não sofrem mais inundação devido ao recuo do mar, que atingiu seu último ápice no litoral brasileiro há $5.100 \mathrm{AP}$ (SUGUIO; MARTIN, 1978). Sua área de maior abrangência geográfica se encontra em toda a extensão da zona litorânea, sendo interceptada pelas planícies intermareais.

- Área de colúvio, terraço e planície fluvial (Actpf): devido à escala adotada neste trabalho, não foi possível diferenciar os colúvios dos terraços em certos pontos, por isso a adaptação metodológica de Furrier (2007) foi utilizada. Os colúvios são porções de terras formadas pelo material transportado de um local para outro, principalmente, pela gravidade. O material coluvial só aparece no sopé de vertentes ou em lugares muito afastados de declives que lhe estão acima (GUERRA; GUERRA, 1997). Esse tipo de forma ocupa cerca de $5 \mathrm{~km}^{2}$ da área. As principais áreas de ocorrência dessas formas estão nas vertentes voltadas para o vale do alto curso do rio da Salsa, alto curso do riacho Estiva e do riacho do Caboclo (Figura 3).

$5^{\circ}$ táxon (formas de vertentes) - para analisar as formas de vertentes correspondentes ao $5^{\circ}$ táxon, foi preciso o auxílio da imagem Modelo Digital de Elevação (MDE) (Figura 4) e também de algumas projeções topográficas executadas no SIG Spring. As principais formas de vertentes encontradas foram vertentes convexas, retilíneas e convexo-retilíneas. Porém, em algumas cabeceiras de drenagem em forma de anfiteatro também existem vertentes côncavas. 
Barbosa T. S. et al.

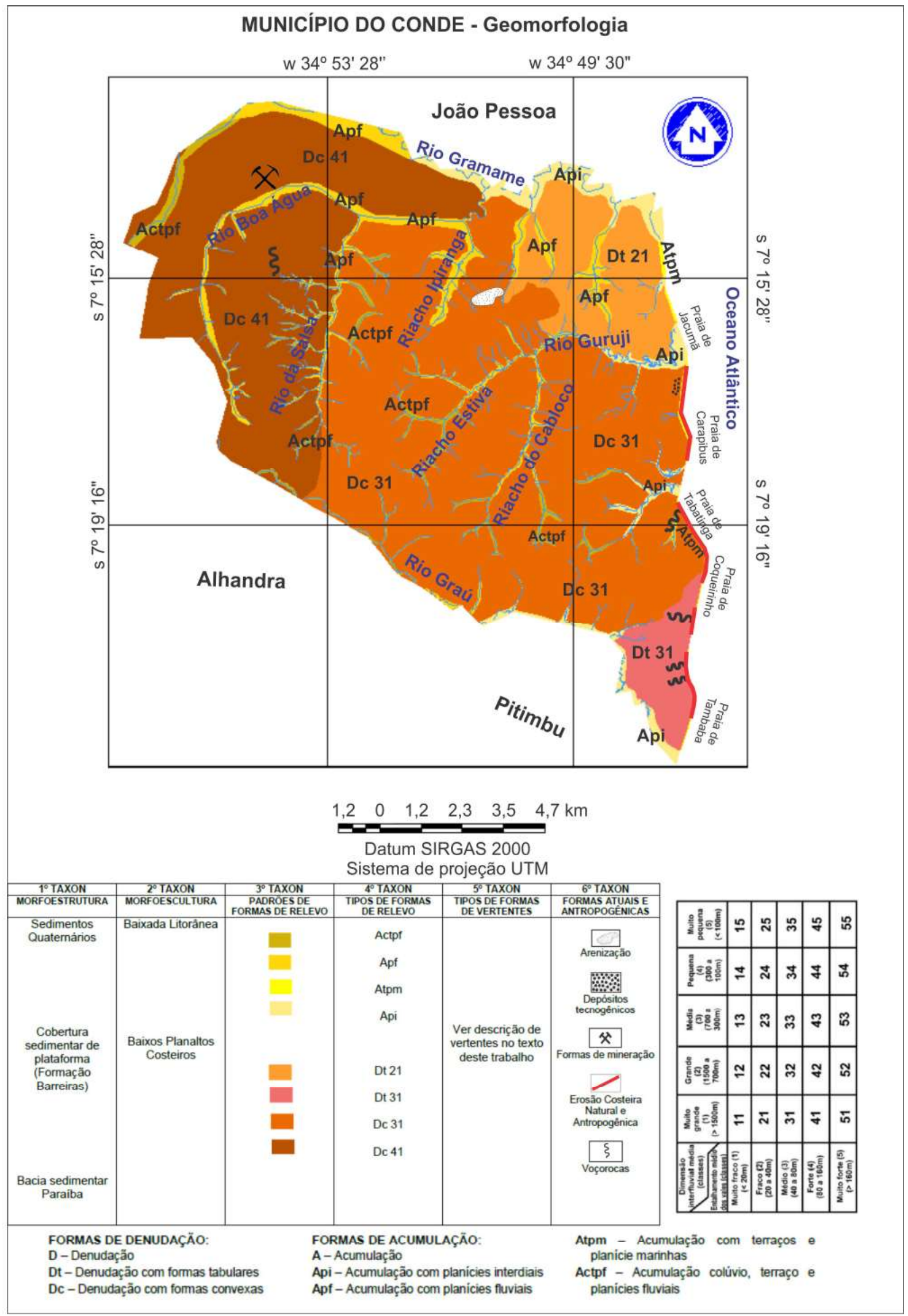

Figura 3 - Mapa geomorfológico do município do Conde. Fonte: Elaboração própria (2018). 


\section{Mapeamento Geomorfológico e Geomorfologia Antropogênica do Município do Conde - Paraíba}

No rio Boa Água pôde-se encontrar vertentes convexas na margem esquerda e convexo-retilíneas na margem direita. No rio da Salsa as vertentes da margem esquerda são caracterizadas por serem convexo-retilíneas $\mathrm{e}$ as da direita convexas. Nos riachos Estiva e do Caboclo ambas as margens contam com vertentes convexas. E o rio Guruji é caracterizado por ter em sua margem direita vertente convexa e na margem esquerda vertente retilínea e convexa, neste mesmo rio existem vertentes côncavas nas cabeceiras de drenagem em formato de anfiteatro (Figura 4).

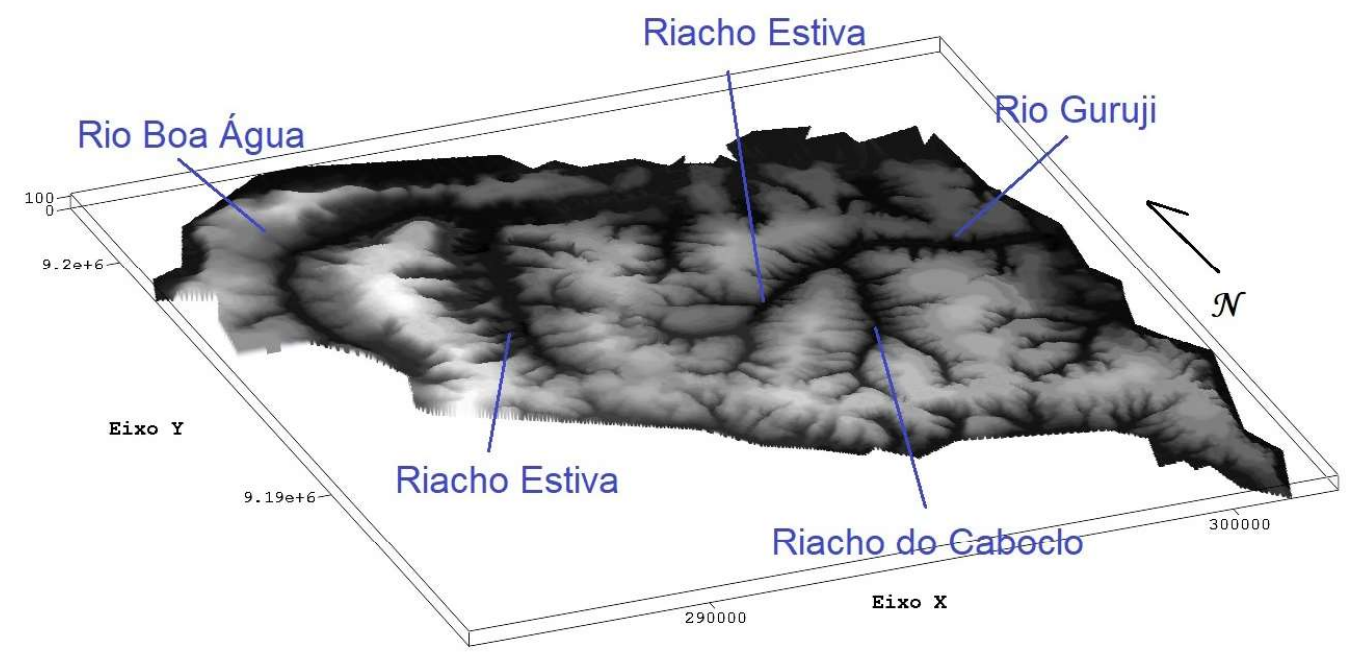

Figura 4 - Imagem 3D do município do Conde. Fonte: Elaboração própria (2018).

$6^{\circ}$ táxon - corresponde às formas de relevo atuais. Dentre elas, as formas tecnogênicas, que serão agora relatadas de acordo com o que foi mapeado no mapa geomorfológico e também com os trabalhos de campo elaborados. No mapa geomorfológico, foram descritos no sexto táxon para o município do Conde as áreas de arenização, depósitos tecnogênicos, formas relacionadas à atividade de mineração, erosão costeira natural e antropogênica e voçorocas.

As áreas de arenização identificadas são oriundas de processos naturais quaternários, principalmente pelo processo de etchplanação (PASSOS e BIGARELLA, 2001), em que áreas planas nos topos dos Baixos Planaltos Costeiros sofrem intensos processos de intemperismo químico, restando apenas minerais de quartzo nesse processo, sendo os demais minerais e elementos lixiviados (FURRIER, 2007). Esses areais, em muitos casos, são minerados de maneira clandestina, produzindo diversas formas antropogênicas.

Com a utilização de imagens de satélite, foram distinguidas possíveis áreas de arenização ou mineração. Por se tratar, em sua maioria, de áreas privadas e cercadas, não foi possível ter acesso à maioria delas, para então constatar que realmente se tratava de um processo de arenização. No entanto, em trabalho de campo foi possível detectar e ter acesso a uma grande área em processo de arenização no município do Conde, na comunidade denominada de Guruji.

Nessa área de arenização (Figura 3), encontram-se diversas formas de origem antropogênicas resultantes da atividade de extração de areia. Segundo a proposta de mapeamento de relevo tecnogênico indicada por Peloggia et al. (2014), trata-se de uma paisagem tecnogênica, que são áreas amplas com extenso e típico relevo transformado ou produzido pela ação humana.

Essa área específica de arenização contém cerca de $140.000 \mathrm{~m}^{2}$ de extensão, e vai compor um terreno tecnogênico escavado, porque há formas denudacionais causadas pela extração de areia, porém pode ser considerado, também, um terreno complexo, segundo Peloggia (2017), pois, além das formas de denudação, há, também, formas de acumulação, tanto naturais, por vias eólicas, quanto antropogênicas (Figura 5).

Em relação aos depósitos tecnogênicos e obedecendo à distinção conceitual entre os terrenos tecnogênicos, camadas tecnogênicas, depósitos tecnogênicos e horizontes de solo tecnogênicos de Peloggia (2017), pôde-se constatar em campo alguns desses terrenos tecnogênicos (Figura 6) apontados na região adjacente à fábrica de cimento embargada (Cimpor), que foi mapeada no mapa geomorfológico (Figura 3) como área de mineração, próxima ao rio Boa Água. 


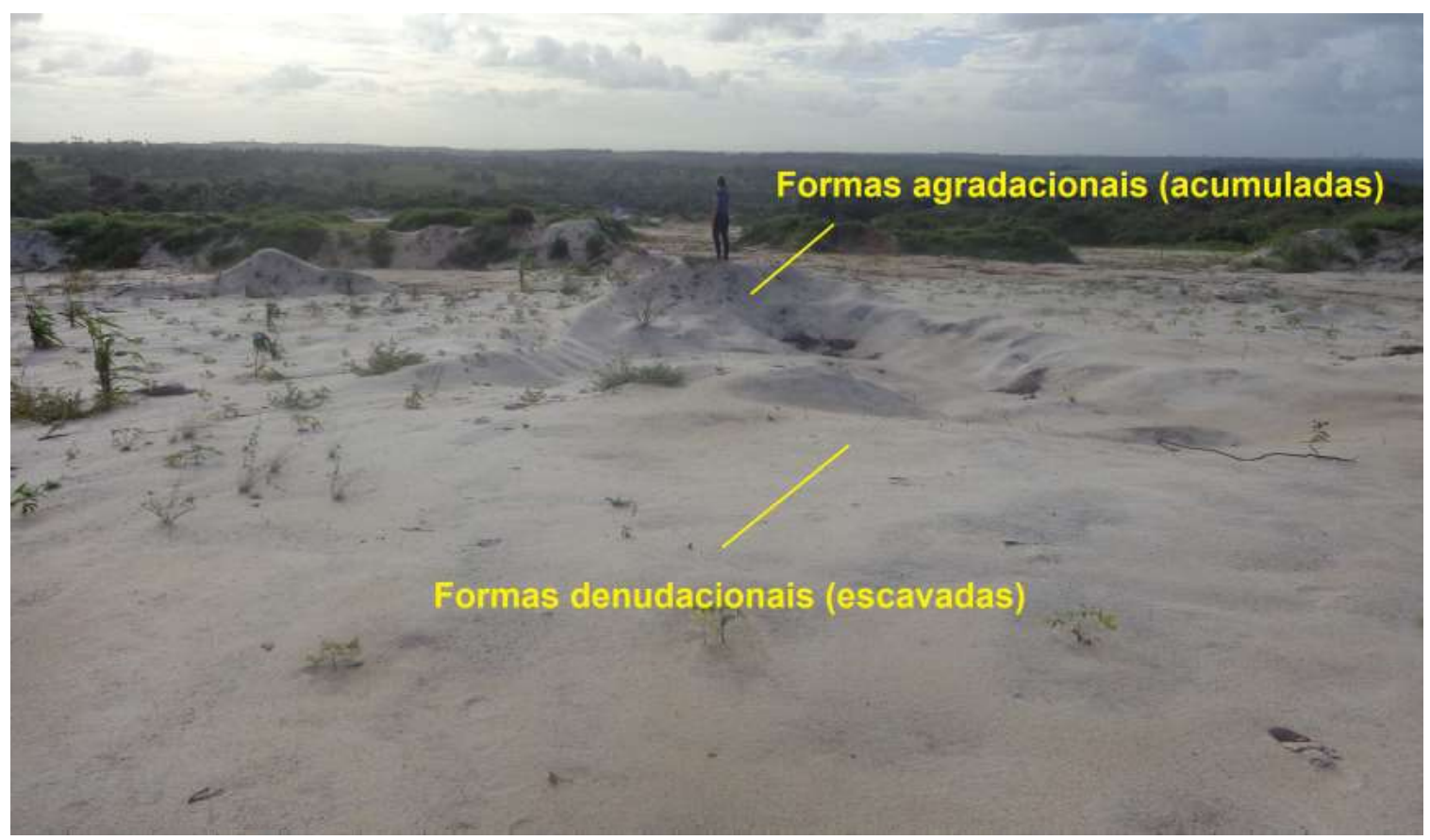

Figura 5 - Área em processo de arenização no município do Conde. Fonte: Elaboração própria (2018).

Na Figura 6 "a" e "b", pode-se notar a presença de camadas tecnogênicas, que são depósitos ou horizontes de solo tecnogênicos. Trata-se de um terreno mecanicamente alterado, devido, provavelmente, às atividades de construção da fábrica de cimento que fica ao lado, resultando, assim, na modificação da composição da camada superior do solo, que apresenta, após essa alteração, presença rica de pequenos fragmentos de rochas graníticas que não são provenientes dessa região, como se pode constatar no mapa geomorfológico do município (ver Figura 3). Na Figura 6 "c", o solo se apresenta também modificado, tratando-se de horizontes de solo tecnogênicos, provavelmente modificados in situ por ação humana.
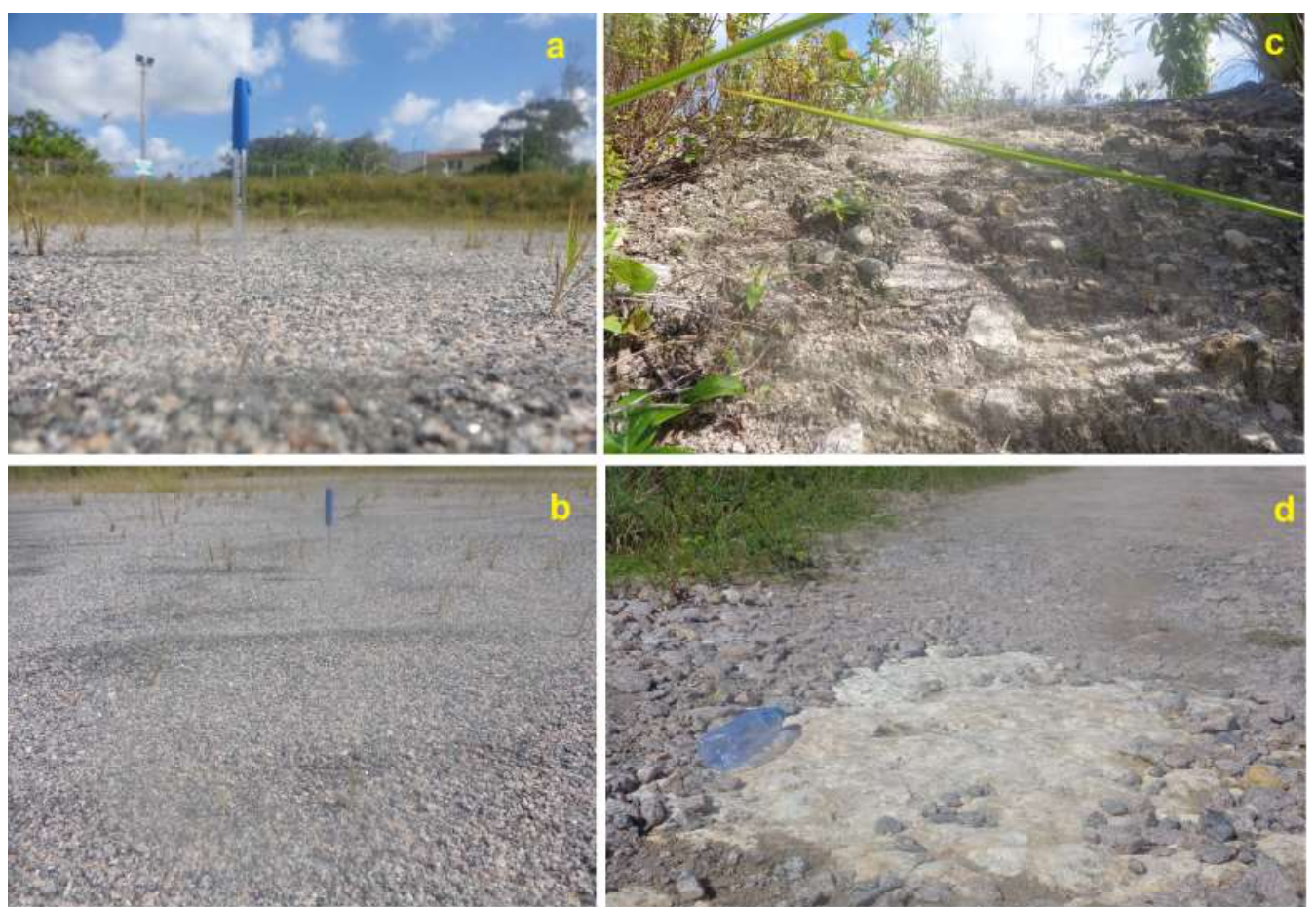

Figura 6 - Modificações tecnogênicas do solo no município do Conde-PB. Fonte: Elaboração própria (2018). 
A Figura 6 "d" pode ser chamada de terreno tecnogênico formado por materiais geológicos ou por exposições de substrato natural antes não aflorante, em virtude de ações de deposição ou remoção direta ou induzida (PELOGGIA, 2017), que, neste caso específico, trata-se de um possível afloramento de rocha calcária, proveniente da bacia sedimentar da Paraíba, que foi causado pelas atividades de construção da fábrica de cimento ao lado.

Em relação às formas de erosão tecnogênicas, foram encontrados sulcos antropogênicos e voçorocas, que, mesmo tendo origem natural, passam por modificação na evolução dos processos que a tangem.
A voçoroca é uma escavação no solo ou na rocha sedimentar branda, ocasionada pela erosão do lençol de escoamento superficial (GUERRA; GUERRA, 1997).

Em regiões urbanas, as voçorocas têm seus processos erosivos intensamente acelerados, devido a fatores como: impermeabilização do solo da cidade e aumento do escoamento de águas pluviais em direção à voçoroca; desmatamento das áreas adjacentes e aumento do aporte de sedimentos; ocupação das áreas contíguas à voçoroca; e um grande agravante que, inclusive, acontece em uma voçoroca urbana no centro da cidade do Conde (Figuras $7 \mathrm{e}$ 8), que é o acumulo de detritos e lixo orgânico nas margens da área de declive da voçoroca e também em seu interior.

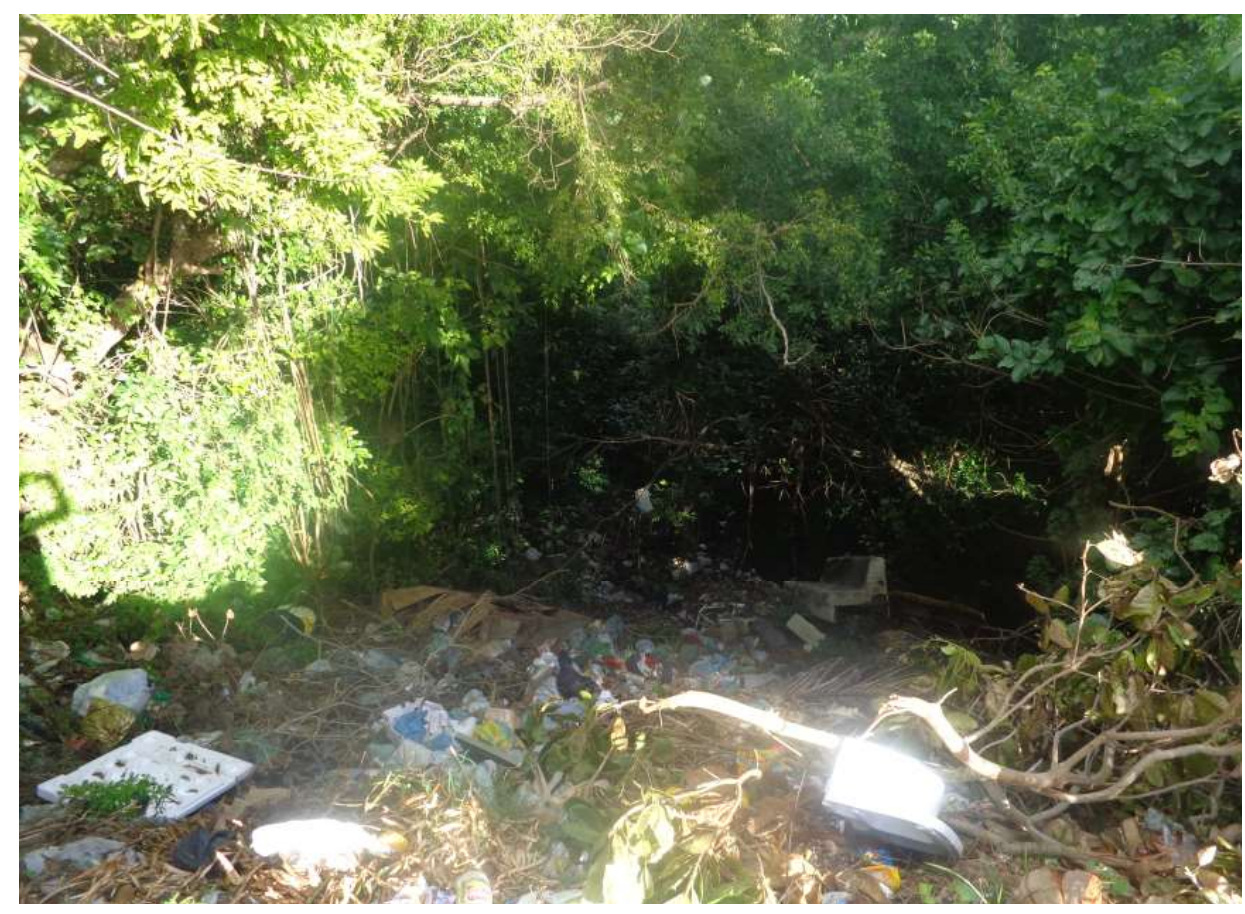

Figura 7 - Acúmulo de lixo orgânico em voçoroca no centro da cidade do Conde - PB. Fonte: Elaboração própria (2018).

Essa voçoroca urbana que se encontra mapeada (Figura 3) tem cerca de $2.700 \mathrm{~m}^{2}$ de extensão, e é rodeada por ocupação urbana, com casas que distam cerca de 10 a $20 \mathrm{~m}$ dela, conforme se pode constatar na Figura 8 .

As voçorocas do município do Conde não se restringem só a essa região do centro da cidade, mas são bem mais presentes na zona litorânea, onde se contabilizam pelo menos quatro grandes voçorocas e outras de menor porte.

O litoral do município do Conde não é completamente urbanizado, principalmente no que diz respeito às áreas em que estão localizadas as grandes voçorocas, mas tem grandes áreas costeiras com mais aspectos naturais que urbanizados, exceto no distrito de Jacumã. Esse fato leva a zona costeira do Conde a passar por dois diferentes processos erosivos: um natural, que é regido pela dinâmica erosiva das voçorocas; e um relacionado à ocupação das zonas costeiras, principalmente na região da praia de Carapibus.

Porém, mesmo na área de erosão natural dominada pelas voçorocas, existe um agravante trazido pela ação antropogênica, pois as regiões contíguas às voçorocas se encontram loteadas e já existem alguns elementos urbanos sobre esses loteamentos (Figura 9), como início de construções de alvenaria, casas prontas, rede de iluminação pública com postes de energia elétrica etc. (Figura 10). 
Barbosa T. S. et al.

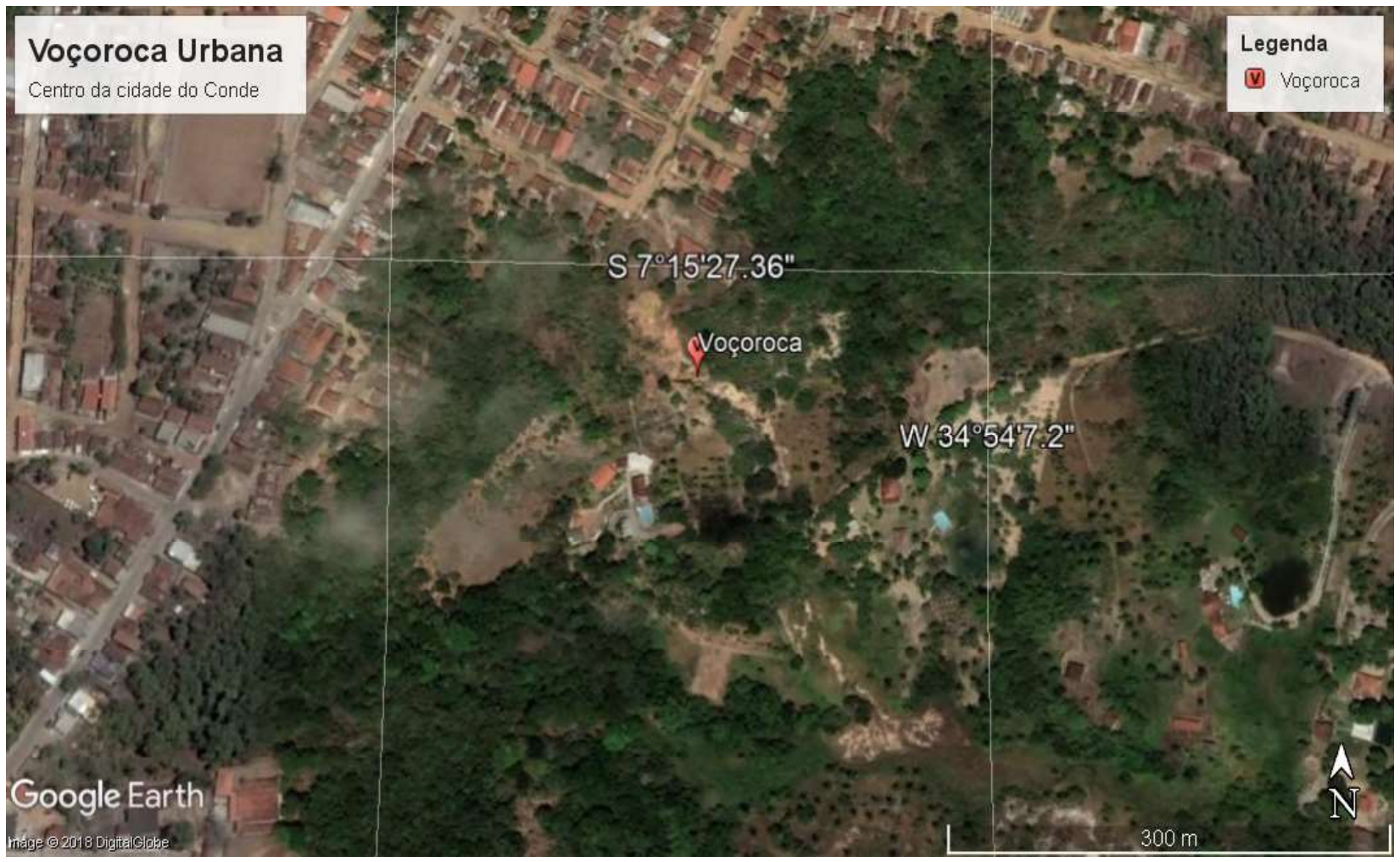

Figura 8 - Voçoroca urbana no centro da cidade do Conde - PB. Fonte: Google Earth (2018).

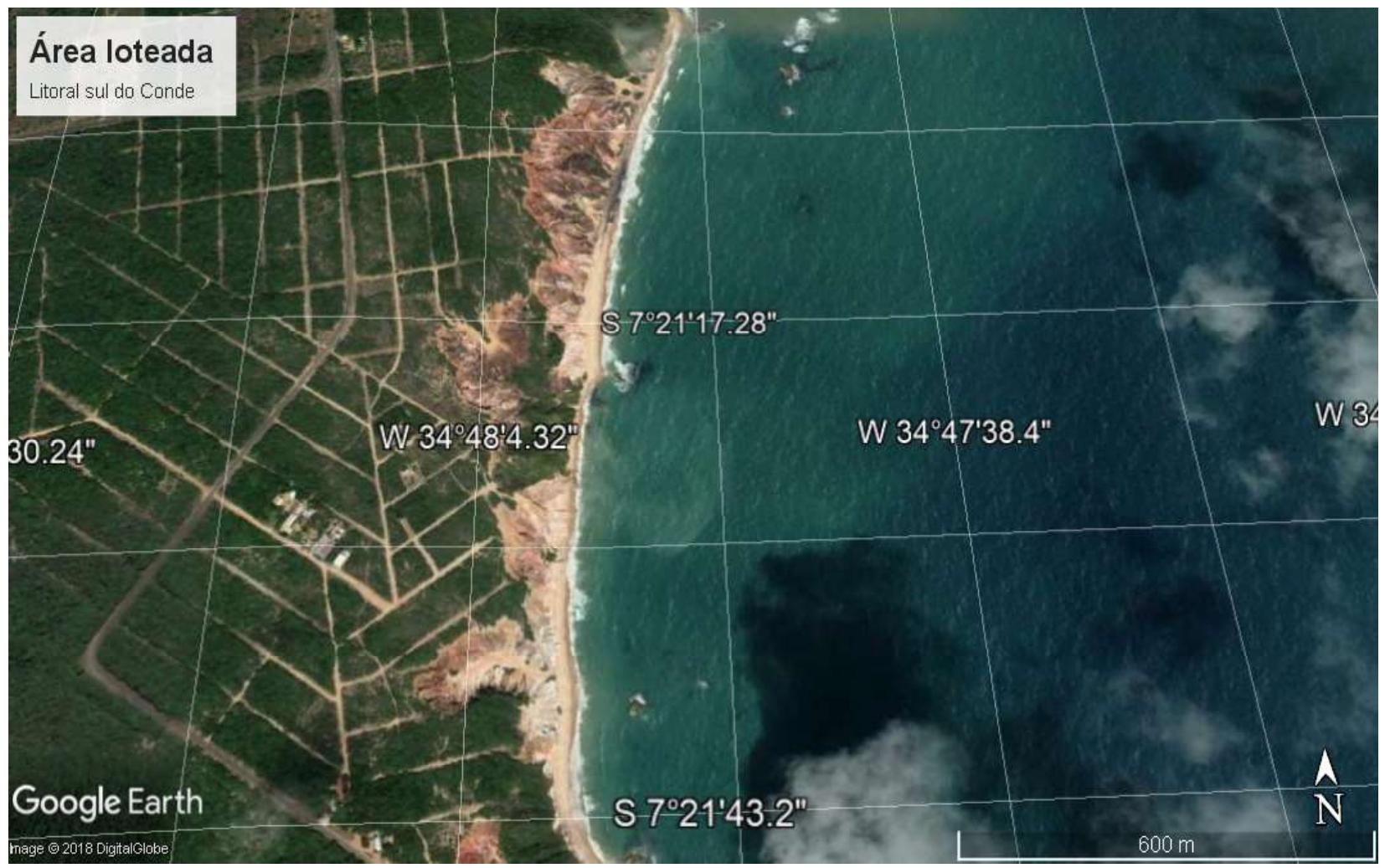

Figura 9 - Zona do litoral sul do Conde com voçorocas e áreas loteadas. Fonte: Google Earth (2018). 


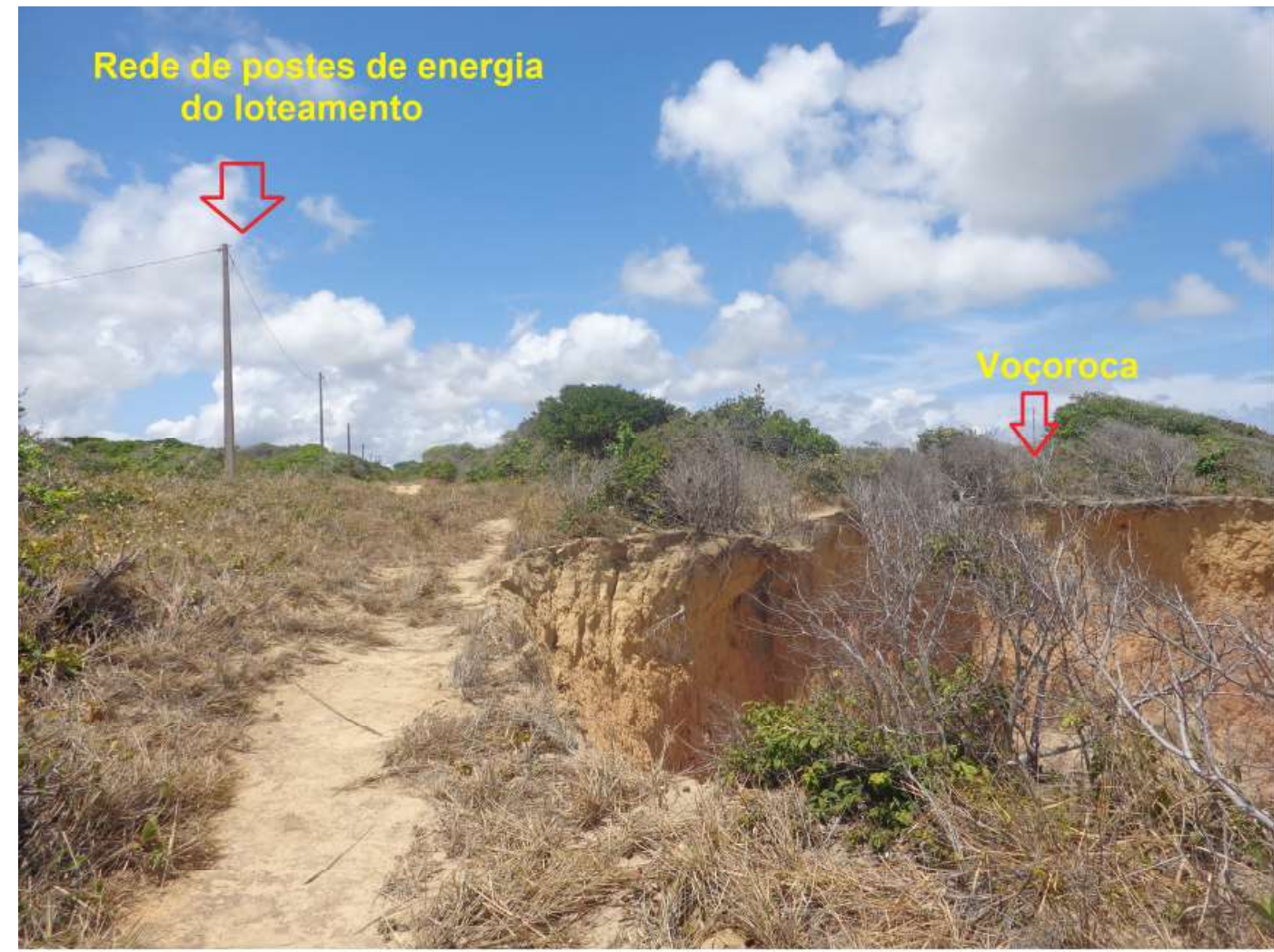

Figura 10 - Voçoroca próxima a uma rede de postes de energia elétrica em loteamento na zona do litoral sul do Conde. Fonte: Elaboração própria (2018).

Nessa região, onde há formação geológica sedimentar e formas de relevo suscetíveis à erosão natural, há também grande tendência à degradação do terreno. Os elementos urbanos sobre essas condições geológicas e geomorfológicas vão acelerar os processos erosivos e, consequentemente, os morfogenéticos. Assim, mesmo não gerando formas agradacionais ou denudacionais de relevo antropogênico, não deixa de ser um terreno com tais características de modificação por vias indiretas da ação humana.

O segundo processo de erosão nas zonas litorâneas que o município do Conde apresenta é relacionado à ocupação das zonas costeiras, ou seja, nas praias urbanas, principalmente de Carapibus e Jacumã. É importante ressaltar que a erosão nas praias urbanas é, em sua maioria, causada pela ocupação irregular da zona costeira, com prédios, casas de veraneio e bares que avançam em direção à praia, sendo, também, uma questão de observação da legislação de ocupação da orla marítima, que, quando é desobedecida, gera problemas de erosão costeira envolvendo riscos de perdas e danos materiais e pessoais.
Na praia de Jacumã, além da erosão costeira relatada, distingue-se, também, no mapa geomorfológico (Figura 3), uma área denominada de depósito tecnogênico. Isso se deve ao fato de que está sendo executada uma obra para construção de calçadão e áreas de lazer nessa parte do litoral do município do Conde.

Havia nessa praia 24 quiosques, que foram retirados devido aos problemas causados pela erosão, a partir de então, começou a construção do calçadão e também obras de contenção para diminuição da energia das ondas nessa praia, o que ocasionaria em uma amenização da erosão natural.

O material utilizado para o aterro da planície costeira e posterior construção do calçadão é completamente diferente dos sedimentos localizados in situ (Figura 11), o que pode causar uma mudança ainda maior na dinâmica natural da área na questão da troca de sedimentos. Sem contar que a barragem ou quebra-mar construído para diminuir a energia das ondas é uma ferramenta que não resolve o problema da erosão costeira, mas o transfere para outra região da costa e, assim, torna-se um efeito dominó. 


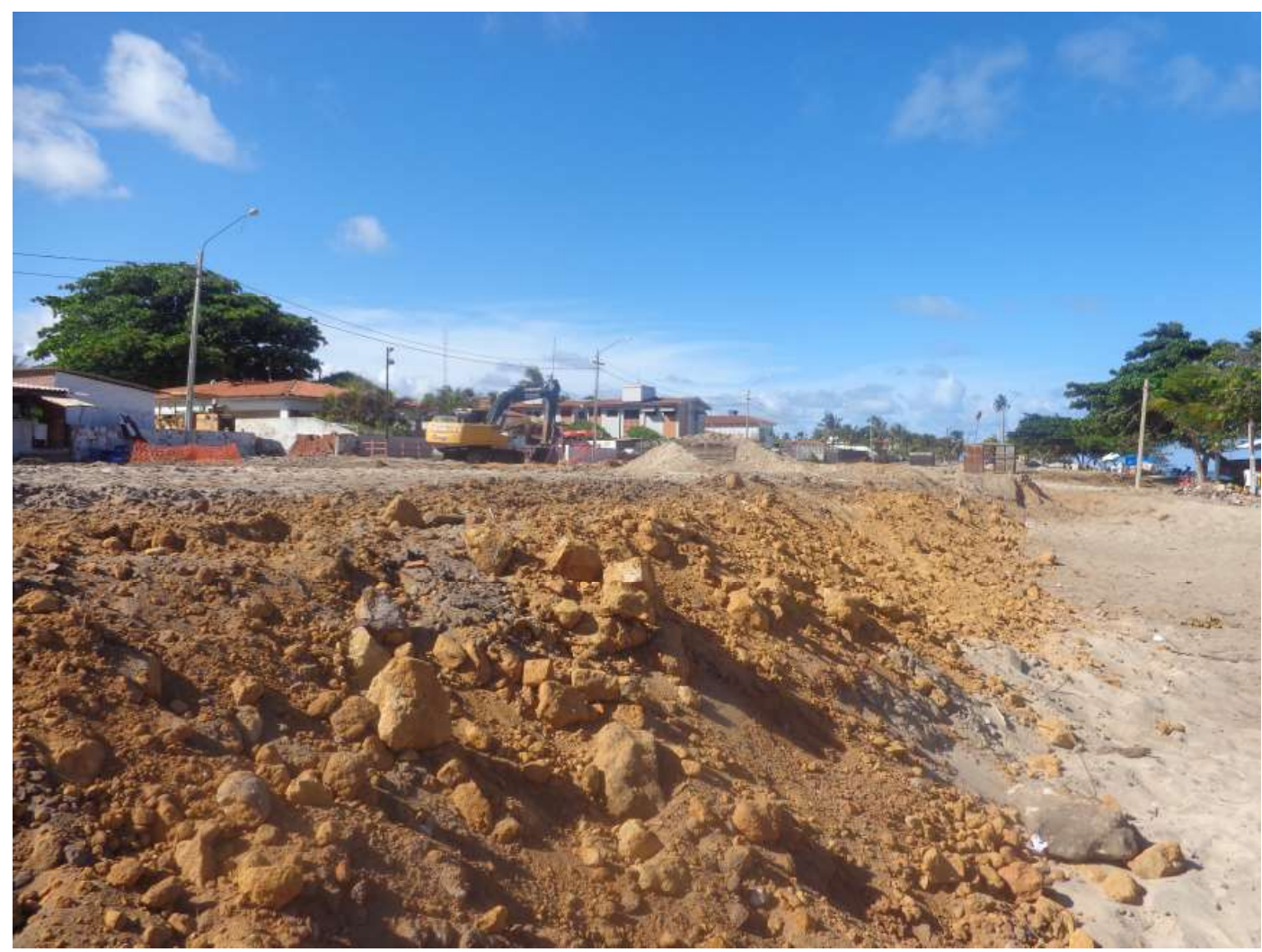

Figura 11 - Depósito tecnogênico úrbico, servindo como aterro da planície costeira para construção de calçadão e áreas de lazer na praia de Jacumã, Conde-PB. Fonte: Elaboração própria (2018).

Com todas essas mudanças diretamente causadas pela ação antropogênica e que alteram os processos morfogenéticos da costa, essa área pode ser considerada como um terreno tecnogênico com depósitos úrbicos de estrutura acamada, que são os formados por materiais terrosos em sobreposição de camadas distintas ou não (PELOGGIA, 2017).

\section{Conclusões}

O mapa geomorfológico elaborado nesta pesquisa fornece subsídios ao planejamento e ao ordenamento do território do município do Conde e pode servir como base para elaboração de estudos com a mesma perspectiva em outros municípios situados sobre a mesma unidade geoambiental.

O mapeamento realizado permitiu identificar 3 unidades morfoestruturais, 2 unidades morfoesculturais e 8 padrões de formas de relevo diferentes. Além disso, ainda foi possível identificar as formas e os tipos de vertentes, destacando-se as formas convexas, retilíneas e convexo-retilíneas.
No $6^{\circ}$ táxon, considerado o de maior relevância nesta pesquisa, por se tratar das formas atuais naturais $\mathrm{e}$ antropogênicas, foram identificadas para o município do Conde as áreas de arenização, depósitos tecnogênicos, formas relacionadas à atividade de mineração, erosão costeira natural e antropogênica e voçorocas. Formas naturais de erosão, como voçorocas ou erosão costeira, mesmo que tenham origem natural, podem ser agravadas por atividades humanas, sendo possível de serem enquadradas como relevo antropogênico.

A metodologia empregada nessa pesquisa, usando escala de detalhe, nos permitiu alcançar o entendimento das relações entre o relevo e o padrão litológico, realçando as feições tecnogênicas resultantes da interface entre ambos, que, associados com as alterações humanas, dão origem à configuração atual do relevo. Dessa forma, é preciso ressaltar que quanto maior a escala empregada, maior será a possibilidade de observação e entendimento da morfologia e das peculiaridades morfométricas da região, permitindo, assim, propiciar meios pelos quais outros trabalhos sejam desenvolvidos na perspectiva de apresentar 
informações detalhadas do terreno, de maneira que os processos naturais e antrópicos possam ser conhecidos visando uma melhor eficiência no planejado da área.

As informações apresentadas sobre as feições do relevo e sua dinâmica, bem como dados quantitativos e qualitativos importantes, tais como a dissecação do relevo, entalhamento de vales, depósitos tecnogênicos e voçorocas, tornam esta pesquisa relevante e contribui para que as ocupações ocorram considerando as fragilidades e potencialidades ambientais, o que favorece, portanto, a sustentabilidade e a qualidade de vida da sociedade. Ao mesmo tempo, oferece subsídios para a realização de novos estudos que aprofundem essas temáticas.

\section{Agradecimentos}

À CAPES e à Fundação de Apoio à Pesquisa do Estado da Paraíba (Fapesq), pelo financiamento da pesquisa por meio da concessão de bolsa de doutorado.

\section{Referências Bibliográficas}

BRAGA, E.; Peloggia, A. U. G.; OliveirA, A. M. S. Análise de risco geológico em encostas tecnogênicas urbanas: o caso do Jardim Fortaleza (Guarulhos, SP, Brasil). Revista UNG - Geociências v. 15, n. 1, p. 27-42, 2016.

CPRM - SERVIÇO GEOLÓGICO DO BRASIL. Ministério de Minas e Energia. Geologia e recursos minerais do Estado da Paraíba. Recife: CPRM, 2002.

CPRM - SERVIÇO GEOLÓGICO DO BRASIL. Projeto cadastro de fontes de abastecimento por água subterrânea. Diagnóstico do município de Conde, estado da Paraíba/ Organizado [por] João de Castro Mascarenhas, Breno Augusto Beltrão, Luiz Carlos de Souza Junior, Franklin de Morais, Vanildo Almeida Mendes, Jorge Luiz Fortunato de Miranda. Recife: CPRM/PRODEEM, 2005.

FIGUEIRA, R. M. Evolução dos sistemas tecnogênicos no município de São Paulo. Dissertação (Mestrado em Geologia Sedimentar), Instituto de Geociências, Universidade de São Paulo, 2007, 126p.

FURRIER, M. Caracterização geomorfológica e do meio físico da Folha João Pessoa 1:100.000. 2007. 213 f. Tese (doutorado) - Faculdade de Filosofia, Letras e Ciências Humanas, São Paulo: USP, 2007.

FURRIER, M.;ARAÚJO, M. E.; MENESES, L. F. Geomorfologia e tectônica da formação Barreiras no Estado da Paraíba. Geologia USP Série Científica, São Paulo, v. 1, n. 6, p. 61-70, 2006.

FURRIER, M.; BARBOSA, T. S. Geomorphology of João Pessoa municipality and its anthropogenic and environmental aspects. Journal of Urban and Environmental Engineering (JUEE), v.10, n.2, p.242-253, 2016.

GOUDIE, A. S. The human impact on the natural environment: past, present and future. 7th ed. Hoboken: John Wiley \& Sons, 2013. 410 p.

GOUVEIA, I. C. M-C. Da originalidade do sítio urbano de São Paulo às formas antrópicas: aplicação da abordagem da Geomorfologia Antropogênica na bacia hidrográfica do rio Tamanduateí, na Região Metropolitana de São Paulo. 2010. 363 f. Tese (Doutorado em Geografia Física) - Faculdade de Filosofia, Letras e Ciências Humanas, Universidade de São Paulo, 2010.

GUERRA, A. T.; GUERRA, A. T. J. Novo dicionário geológicogeomorfológico. Rio de Janeiro: Bertrand Brasil, 1997.

HOOKE, R. L. On the efficacy of humans as geomorphic agents. GSA Today, v. 4, n. 9, p. 217, 224-225, 1994.

LUZ, R. A.; RODRIGUES, C. Anthropogenic changes in urbanised hydromorphological systems in a humid tropical environment: River Pinheiros, São Paulo, Brazil. Zeitschrift für Geomorphologie, v. 59, n. 2, Supplementary Issues, p. 109-135, 2015.

NIR, D. Man, a geomorphological agent: an introduction to anthropic geomorphology. Jerusalem: Keper Publishing House; Dordrecht: D. Reidel Publishing, 1983.

PASSOS, E.; BIGARELLA, J. J. Superfícies de erosão. In: CUNHA, S. B.; GUERRA,

A. J. T. (Org.). Geomorfologia do Brasil. Rio de Janeiro: Bertrand Brasil, 2001. p. 107-142.

PELOGGIA, A. U. G. O que produzimos sob nossos pés? Uma revisão comparativa dos conceitos fundamentais referentes a solos e terrenos antropogênicos. Revista UNG - Geociências, v. 16, p. 102-127, 2017.

PElOGGIA, A. U. G.; SILVA, E. C. N.; NUNES, J. O. R. Technogenic landforms: conceptual framework and application to geomorphologic mapping of artifi cial ground and landscapes as transformed by human geological action. Quaternary and Environmental Geosciences, 2014.

PELOGGIA, A. U. G.; SAAD, A. R.; SILVA, R. V.; QUEIROZ, W. Processos de formação de terrenos e relevos tecnogênicos correlativos a urbanização: análise morfoestrátigráfica e geoambiental aplicada na bacia do córrego Água Branca, 
Itaquaquecetuba (RMSP). Revista Brasileira de Geomorfologia. v. 19 , n. 2, 2018. p. 245-265.

RODRIGUES, C. Morfologia original e morfologia antropogênica na definição de unidades espaciais de planejamento urbano: exemplo na metrópole paulista. Revista do Departamento de Geografia, n. 17, p. 101-111, 2005.

ROSS, J. L. S. O registro cartográfico dos fatos geomórficos e a questão da taxonomia do relevo. Revista do Departamento de Geografia, (FFLCH-USP), p. 17-29, 1992.

SUDENE-SUPERINTENDÊNCIADEDESENVOLVIMENTO

DO NORDESTE. Folhas Nossa Senhora da Penha, Santa
Rita, João Pessoa, Conde, Jacumã e Mata da Aldeia. Recife: Sudene, 1974. Escala 1:25.000.

SUGUIO, K.; MARTIN, L. Quaternary marine formations of the State of São Paulo and southern Rio de Janeiro. In: International Symposium on Coastal Evolution in The Quaternary, São Paulo. Special Publication, n. 1, 1978.

SZABÓ, J. Anthropogenic geomorphology: subject and system. In: SZABÓ, J.; DÁVID, L.; LÓCZY, D. (Eds.). Anthropogenic Geomorphology: A Guide to Man-Made Landforms. London; New York: Springer Science+Business Media B.V., DordrechtHeidelberg, 2010. 